\title{
Variability of the climatic mass balance of Vestfonna ice cap, northeastern Svalbard, 1979-2011
}

\author{
Marco MÖLLER, ${ }^{1}$ Roman FINKELNBURG, ${ }^{2}$ Matthias BRAUN, ${ }^{3}$ Dieter SCHERER, ${ }^{2}$ \\ Christoph SCHNEIDER ${ }^{1}$ \\ ${ }^{1}$ Department of Geography, RWTH Aachen University, Aachen, Germany \\ E-mail: marco.moeller@geo.rwth-aachen.de \\ ${ }^{2}$ Department of Ecology, Technische Universität Berlin, Berlin, Germany \\ ${ }^{3}$ Department of Geography, Friedrich-Alexander-University Erlangen-Nürnberg, Erlangen, Germany
}

\begin{abstract}
Vestfonna ice cap, northeastern Svalbard, is one of the largest ice bodies in the European Arctic, but little is known about the evolution of its mass balance. This study presents a reconstruction of the climatic mass balance of the ice cap for the period 1979/80-2010/11. The reconstruction is based on calculations using a mass-balance model that combines a surface-elevation-dependent accumulation scheme with a spatially distributed temperature-index ablation model that includes net shortwave radiation. Refreezing is included, based on the basic $\boldsymbol{P}_{\max }$ approach. The model accounts for cloud-cover effects and surface albedo variations that are calculated by a statistical albedo model. ERAInterim derived air temperature, precipitation and total cloud-cover data are used as input. Results reveal a mean climatic mass-balance rate of $+0.09 \pm 0.15 \mathrm{~m}$ w.e. $\mathrm{a}^{-1}$ for the study period. Annual balances show a slight, insignificant trend towards less positive values over the study period. Refreezing is estimated to contribute about one-third to annual accumulation, and a significant positive trend in refreezing is present over the study period. The modelling results reveal a significant steepening of the climatic mass-balance gradient and indicate a lengthening of the characteristic 3 month ablation period in recent years.
\end{abstract}

\section{INTRODUCTION}

Increasingly negative glacier mass balances around the world have contributed significantly to global sea-level rise in recent decades (Kaser and others, 2006; Radić and Hock, 2011). Glaciers and ice caps in the Arctic play a major role in this process due to their large surface area (Gardner and others, 2011; Jacob and others, 2012). Hence, glacier massbalance records in this region are important for estimates of future global sea-level evolution.

Glaciers on Svalbard cover $34560 \mathrm{~km}^{2}$ (Moholdt and others, 2010a). In spite of this large ice-covered area, longterm mass-balance records from Svalbard are scarce and limited to a few small glaciers. The mass balance of Austre Brøggerbreen and Midre Lovénbreen, both $\sim 5-6 \mathrm{~km}^{2}$ in size and located in the $\mathrm{Ny}$-Ålesund area, have been measured since 1967 and 1968, respectively (Lefauconnier and others, 1999). Shorter records exist for Kongsvegen $\left(102 \mathrm{~km}^{2}\right)$ in the Ny-Ålesund area (Lefauconnier and others, 1999) since 1987 and Hansbreen $\left(57 \mathrm{~km}^{2}\right)$ in the Hornsund area (Jania and others, 1996) since 1988. Rasmussen and Kohler (2007) made a mass-balance reconstruction back to 1948 for Austre Brøggerbreen, Midre Lovénbreen and Kongsvegen, and thus extended the mass-balance records of these glaciers by two decades. Rye and others (2010) presented a reconstruction for Midre Lovénbreen that goes back to 1958. For the larger ice masses of the archipelago, however, neither measured nor reconstructed long-term mass-balance time series exist. A regularly maintained stake network for in situ measurements was installed on Austfonna ice cap in 2004 (Moholdt and others, 2010b).

The aim of this study is to present a reconstructed, monthly, reference-surface climatic mass balance (CMB) time series for Vestfonna ice cap for the period
1979/80-2010/11. The employed mass-balance calculation scheme is based on the model presented by Möller and others (2011a). Daily ERA-Interim (European Centre for MediumRange Weather Forecasts Interim Re-analysis) $2 \mathrm{~m}$ airtemperature data, total precipitation and total cloud cover are used as model input. Accumulation is calculated according to a surface-elevation-dependent scheme calibrated from extensive, in situ snow water equivalent (SWE) measurements (Möller and others, 2011b). Ablation modelling is done using a temperature-index model that includes net shortwave radiation (Pellicciotti and others, 2005). The calculation of glacier-wide net radiation differs from the original model. Möller and others (2011a) employed daily updated Terra MODIS (Moderate Resolution Imaging Spectroradiometer) data for retrieval of surface albedo and cloudcover fields. This study calculates mean monthly surfacealbedo fields according to a statistical approach presented by Möller (2012). Cloud-cover forcing is included as a spatially constant daily value provided by the ERA-Interim dataset.

\section{STUDY AREA}

The polythermal ice cap Vestfonna covers an area of $2340 \mathrm{~km}^{2}$ (Braun and others, 2011) of the island Nordaustlandet (northernmost Svalbard archipelago) at around $80^{\circ} \mathrm{N}$ (Fig. 1) extending between sea level and $\sim 630 \mathrm{~m}$ a.s.l. Along with the much larger neighbouring Austfonna and Icelandic Vatnajökull, it is among the largest ice masses of the European Arctic. The smoothly shaped, dome-like ice body features a main east-west oriented ridge with its highest point, Ahlmann Summit, located almost in the centre. Another main ridge extends northward from a secondary peak located in the eastern part of the ice cap. 
Vestfonna is drained by several outlet glaciers, some of which are suggested to be surge-type (Dowdeswell and Collin, 1990). The majority of the ice body drains to the south into Wahlenbergfjorden, forming five large $(>5 \mathrm{~km})$ calving fronts (Strozzi and others, 2008), while a few smaller outlet glaciers drain to the northeast. The largest outlet glacier, however, is Franklinbreen whose two tongues calve into Lady Franklinfjorden, which is located on the northwestern side of the ice cap. Besides Franklinbreen, which shows signs of a surge, almost all other outlet glaciers show continuous retreat of the ice fronts, although rates are small in relation to the size of the glaciers (Braun and others, 2011).

Climate conditions around Svalbard are characterized by the counteracting influences of cold and warm air masses and ocean waters. The archipelago lies at the intersection of warm and humid air coming from the northern Atlantic Ocean and cold and dry Arctic air masses originating in even more northerly regions (Svendsen and others, 2002). The West Spitsbergen Current that forms the northernmost end of the North Atlantic Current transports comparably warm waters to the western coast of Svalbard (Walczowski and Piechura, 2011). The eastern parts of the archipelago are, in contrast, influenced by cold Arctic ocean currents (Loeng, 1991).

The resulting, maritime climate setting throughout the study area is characterized by a pronounced annual cycle of air temperatures and a fairly homogeneous seasonal precipitation distribution (Fig. 2). Mean monthly air temperatures at an automatic weather station (AWS) at 370 ma.s.I. on Vestfonna (Fig. 1) vary in the range -28 to $+4^{\circ} \mathrm{C}$. Daily variability is distinctly higher in winter than in summer, and short-term, warm periods with air temperatures above the melting point may even occur outside the summer season. Prevailing melting conditions generally occur in the period June to August (Möller and others, 2011a) and often extend over large parts of the ice cap (Rotschky and others, 2011). Easterly weather systems coming from the Barents Sea region provide the major moisture source for precipitation (Førland and others, 1997). Precipitation sums on Vestfonna are thus expected to be smaller than on the larger and higher Austfonna, due to the leeside location of the ice cap (Pinglot and others, 1999). However, there is also evidence for a strong northwesterly influence on precipitation on Vestfonna (Käsmacher and Schneider, 2011). Temporal (i.e. interannual) variability of precipitation on Vestfonna was found to be high by Beaudon and others (2011) while spatial variability across the ice cap is mainly governed by surface elevation (Möller and others, 2011b). The mass-balance year of the ice cap generally lasts from September to August and features a 9 month accumulation and a 3 month ablation period (Möller and others, 2011a).

\section{DATA}

The mass-balance reconstruction model requires terrain elevation and areal extent data of Vestfonna as a basis for all calculations. Daily air temperature, precipitation and cloud cover from the period September 1979 to August 2009 are used as input for running the mass-balance model. They are provided by ERA-Interim data (Dee and others, 2011) for the gridpoint at $79.5^{\circ} \mathrm{N}, 19.5^{\circ} \mathrm{E}$, which is located just south of the ice cap (Fig. 1). The albedo model requires additional, derived data of cumulative positive degree-days (PDD), cumulative snowfall and rain/snow ratio. Records from an

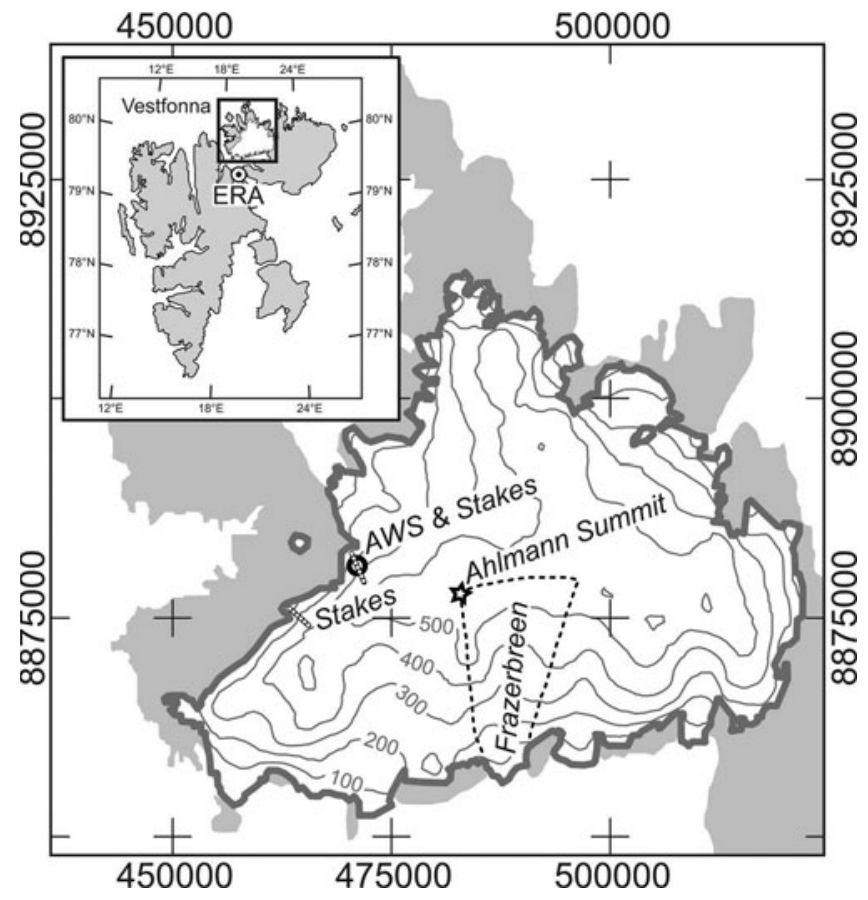

Fig. 1. Overview map of Vestfonna. Coordinates correspond to Universal Transverse Mercator (UTM) zone $34 \mathrm{~N}$. Contour spacing is $100 \mathrm{~m}$. The black circle marks the location of the AWS that is used as an in situ reference. Stake transects used for calibration and validation are indicated by dashed lines. The inset shows an overview map of the Svalbard archipelago. The black circle marks the ERA-Interim gridpoint.

AWS on the ice cap (Fig. 1) serve as an in situ reference during data preparation.

\section{Surface data}

The areal extent of Vestfonna was obtained by manually digitizing the glacier outline on a Terra ASTER (Advanced Spaceborne Thermal Emission and Reflection Radiometer) scene acquired on 17 August 2000 (EOS Data Gateway Granule ID: SC:ASTL1B 00-08-12:36:0010269001). Surface elevations with $250 \mathrm{~m}$ spatial resolution were derived on the basis of the ASTER global digital elevation model (GDEM). Isolated elevation outliers and small areas of data voids in the upper parts of the ice cap were replaced by interpolated values.

\section{Air temperature}

The original ERA-Interim air-temperature data were statistically downscaled using the variance-inflation method (Karl and others, 1990; Huth, 1999) to fit local conditions at the ice cap, following Möller and others (2011a). Variance inflation is a suitable tool for adjusting both annual cycle and daily variance of gridded air temperatures to local conditions (Huth and others, 2001). By applying this method we implicitly assume that air-temperature variability at Vestfonna is exclusively controlled by the synoptic situation (von Storch, 1999). In situ reference for the downscaling was provided by a 2 year air-temperature record from the AWS (Fig. 1), covering the period May 2008 to April 2010. In order to account for the high intra-annual variability of airtemperature variance (Fig. 2), downscaling was done separately for each month, $i(i=1,2, \ldots, 12)$, according to a two-step approach, described by von Storch (1999). In the first step, the original ERA-Interim data, $T_{\text {ERA, } i \text {, were }}$ 

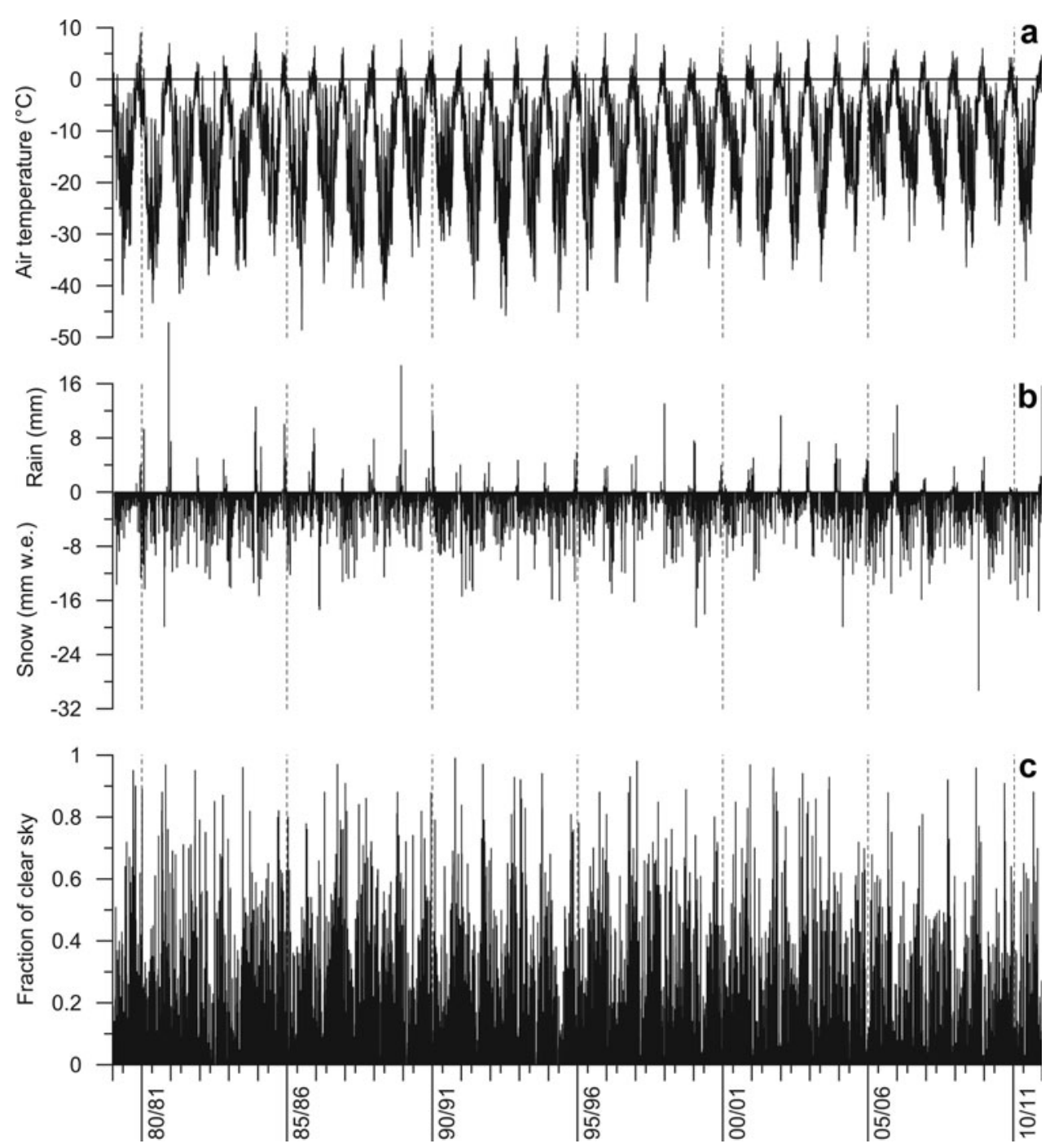

Fig. 2. Time series of meteorological data for the mass-balance years 1979/80-2010/11. (a) The downscaled ERA-Interim air temperatures. (b) Rainfall and snowfall based on scaled ERA-Interim data. (c) The fraction of clear sky, representing the negative of ERA-Interim total cloud cover, displayed for clarity. All values are related to the terrain elevation of the AWS (370 ma.s.l.; Fig. 1) and are shown at daily resolution. Major ticks on the $x$-axis mark the beginning of each mass-balance year, i.e. 1 September. Minor ticks mark the beginning of each calendar year.

Table 1. Overview of coefficients used in data preparation and mass-balance modelling. All values except for $e$ and $f$ are taken from Möller and others (2011a)

\begin{tabular}{|c|c|c|}
\hline Coefficient & Value & Equation \\
\hline$a_{1}, b_{1}$ & $-2.73^{\circ} \mathrm{C}, 1.10$ & 1 \\
\hline$a_{2}, b_{2}$ & $-4.26^{\circ} \mathrm{C}, 0.90$ & 1 \\
\hline$a_{3}, b_{3}$ & $-1.79^{\circ} \mathrm{C}, 1.05$ & 1 \\
\hline$a_{4}, b_{4}$ & $-3.34^{\circ} \mathrm{C}, 1.00$ & 1 \\
\hline$a_{5}, b_{5}$ & $-3.37^{\circ} \mathrm{C}, 1.08$ & 1 \\
\hline$a_{6}, b_{6}$ & $-2.70^{\circ} \mathrm{C}, 1.30$ & 1 \\
\hline$a_{7}, b_{7}$ & $-2.30^{\circ} \mathrm{C}, 1.20$ & 1 \\
\hline$a_{8}, b_{8}$ & $-4.00^{\circ} \mathrm{C}, 2.01$ & 1 \\
\hline$a_{9}, b_{9}$ & $-2.96^{\circ} \mathrm{C}, 1.26$ & 1 \\
\hline$a_{1} 0, b_{1} 0$ & $-2.57^{\circ} \mathrm{C}, 1.06$ & 1 \\
\hline$a_{1} 1, b_{1} 1$ & $-3.10^{\circ} \mathrm{C}, 1.02$ & 1 \\
\hline$a_{1} 2, b_{1} 2$ & $-2.74^{\circ} \mathrm{C}, 1.02$ & 1 \\
\hline$c, d$ & $0.99 \times 10^{-5} \mathrm{~m}^{-2}, 0.79 \times 10^{-2} \mathrm{~m}^{-1}$ & 3 \\
\hline e & $1.736 \mathrm{~mm}$ w.e. $\mathrm{K}^{-1} \mathrm{~d}^{-1}$ & 5 \\
\hline$f$ & $0.141 \mathrm{~mm}$ w.e. $\mathrm{W}^{-1} \mathrm{~m}^{2} \mathrm{~d}^{-1}$ & 5 \\
\hline$g$ & 0.364 & 10 \\
\hline
\end{tabular}

adjusted to local conditions at the ice cap according to the linear scaling function

$$
\widehat{T}_{\mathrm{ERA}, i}=a_{i}+b_{i} T_{\mathrm{ERA}, i}
$$

Coefficients $a_{1-12}$ and $b_{1-12}$ (Table 1 ) were determined by Möller and others (2011a) using linear regression analysis between the original ERA-Interim data and the AWS records. In the second step of the downscaling procedure, the variance of $\widehat{T}_{\mathrm{ERA}, i}$ was increased to the one evident at the AWS site according to

$$
T_{i}=\sqrt{\frac{\operatorname{var}\left(T_{\mathrm{AWS}, i}\right)}{\operatorname{var}\left(\widehat{T}_{\mathrm{ERA}, i}\right)}}\left(\widehat{T}_{\mathrm{ERA}, i}-\overline{\widehat{T}_{\mathrm{ERA}, i}}\right)+\overline{\widehat{T}_{\mathrm{ERA}, i}}
$$

The monthly mean air temperature, $\overline{\widehat{T}_{\mathrm{ERA}}, i}$, was subtracted out before increasing the variance and re-added afterwards. This procedure differs from the one outlined by von Storch (1999). It was used in order to avoid the introduction of a bias for months with a nonzero mean air temperature. By doing this we deviate from the approach used by Möller and others (2011a) and were able to increase the accuracy of 
downscaled air temperatures. While Möller and others (2011a) achieved root-mean-square errors (rmse) of $0.7 \mathrm{~K}$ (June-August) and $1.2 \mathrm{~K}$ (September-May) compared to AWS records, here the rmse could be distinctly reduced to $0.4 \mathrm{~K}$ (June-August) and $0.3 \mathrm{~K}$ (September-May). To allow for the variability of air temperature with surface elevation, a constant linear lapse rate of $-7.0 \mathrm{~K} \mathrm{~km}^{-1}$ is used (Möller and others, 2011a).

\section{Precipitation}

The original ERA-Interim precipitation data are distributed over the ice cap by quadratic scaling according to terrain elevation. The associated function of terrain elevation, $z$, was derived from an analysis of SWE measurements carried out across the ice cap in the years 2007-10 (Möller and others, 2011b) and given by Möller and others (2011a):

$$
P(z)=P_{\mathrm{ERA}}\left(c z^{2}+d z+1\right)
$$

This scaling relationship assumes that precipitation is equal to the original ERA-Interim value at sea level and increases by up to more than nine times to the uppermost parts of the ice cap. Coefficients $c$ and $d$ are given in Table 1 .

\section{Derived meteorological quantities}

For modelling of surface albedo three derived meteorological variables are needed (Möller, 2012), i.e. cumulative snowfall, cumulative PDD and the rain/snow ratio. They are incorporated at a monthly resolution and distributed over the ice cap according to terrain elevation. Snowfall and PDD at a specific terrain elevation are summed over the course of each mass-balance year, starting in September, to yield the two variables cumulative snowfall and cumulative PDD.

The third variable, rain/snow ratio, is calculated as the ratio of the monthly sums of rain and snowfall at a specific surface elevation. However, the transition between rain and snow in the albedo model differs from the one in the massbalance model. As the albedo model is designed as a minimal model, a fixed threshold of $0^{\circ} \mathrm{C}$ is used in order to avoid complex threshold calculations (Möller, 2012).

\section{MODEL DESCRIPTION}

The mass-balance reconstruction model calculates the $C M B$, i.e. the sum of surface accumulation, surface ablation and refreezing (Cogley and others, 2011), of Vestfonna for the period September 1979 to August 2009 at a daily resolution. Results are presented and discussed for monthly as well as annual resolution.

The modelling architecture is based on that of Möller and others (2011a) with several modifications. Accumulation is calculated from the scaled ERA-Interim precipitation data. Ablation is calculated using a temperature-index model that includes net shortwave radiation. Statistically downscaled ERA-Interim air-temperature data and modelled net shortwave radiation serve as input to the ablation model. Net shortwave radiation modelling requires surface albedo information that is provided by modelled albedo fields. Refreezing is incorporated using the $P_{\max }$ approach (Reeh, 1991).

\section{Accumulation}

The surface accumulation at terrain elevation $z$ is calculated from the proportion of snowfall of the scaled ERA-Interim precipitation data $(P(z)$, Eqn (3)). This proportion is calculated according to air temperature, $T(z)$, using a hyperbolic function suggested by Möller and others (2007):

$$
c(z)=\frac{P(z)}{2}-\tan [3.0(T(z)-1.0)] \frac{P(z)}{2}
$$

The function describes a continuous transition between snowfall and rain over the range $0-2^{\circ} \mathrm{C}$.

\section{Refreezing}

Refreezing of meltwater within the snow- or firn pack of the glacier is accounted for using the $P_{\max }$ approach introduced by Reeh (1991). In contrast to the original model formulation of Möller and others (2011a) we set $P_{\max }=0.9$ (instead of $0.6)$, according to the findings of a recent energy-partitioning study at Austfonna (Østby and others, 2013). This means that a maximum of $90 \%$ of winter accumulation can be retained by refreezing processes during the following ablation season. After this fraction is reached, any further meltwater production is assumed to result in runoff.

\section{Ablation}

The surface ablation at terrain elevation $z$ is calculated using a temperature-index approach that includes net shortwave radiation (Pellicciotti and others, 2005):

$$
a(z)=e T(z)+f(1-\alpha) R_{\mathrm{G}}
$$

Ablation occurs if air temperature is above $0^{\circ} \mathrm{C}$. The parameters $e$ and $f$ (Table 1 ) were not adopted from the original model of Möller and others (2011a), but were recalibrated based on in situ stake measurements (Calibration and validation subsection below) in order to account for the updated refreezing formulation. $R_{\mathrm{G}}$ is global radiation. Calculation of ablation requires the computation of glacier-wide fields of surface albedo $\alpha$ and global radiation.

\section{Surface albedo}

The surface-albedo fields of Vestfonna are modelled on a monthly basis. A daily updated calculation is not feasible, as frequent snowdrift disturbs local surface characteristics. Modelling is done using a statistical approach, especially designed and calibrated to cope with the conditions at Vestfonna (Möller, 2012). It calculates the mean altitudinal profile of monthly surface albedo according to

$$
\alpha(z)=\Theta(z)-\Psi(z)
$$

In this equation, $\Theta(z)$ is a sigmoid function of rain/snow ratio and $\Psi(z)$ a linear function of cumulative snowfall and cumulative PDD. $\Theta(z)$ is calculated as

$$
\Theta(z)=\frac{\theta_{1}(z)-\theta_{2}(z)}{1+\left(\frac{\Phi_{\mathrm{rsr}}(z)}{\theta_{3}(z)}\right)^{\theta_{4}(z)}}+\theta_{2}(z)
$$

with $\Phi_{\mathrm{rsr}}(z)$ being the rain/snow ratio at terrain elevation $z$. $\theta_{1-4}$ are empirical parameter functions that express variability of the parameters with terrain elevation, $z$ (Table 2). $\Psi(z)$ is calculated as

$$
\Psi(z)=\psi_{1}(z)+\psi_{2}(z) \Phi_{\text {csf }}(z)+\psi_{3}(z) \Phi_{\text {c_spdd }_{-}}(z)
$$

with $\Phi_{\text {csf }}(z)$ and $\Phi_{\text {c_spdd }}(z)$ being cumulative snowfall and cumulative PDD. The empirical parameter functions, $\psi_{1-3}$, also vary with terrain elevation, $z$ (Table 2 ).

\section{Global radiation}

Spatially distributed global radiation at the glacier surface is calculated as the sum of cloud-cover-reduced direct solar 
Table 2. Parameter functions of the albedo model (Eqns (7) and (8)), according to Möller (2012)

\begin{tabular}{lc} 
Parameter & Function \\
\hline$\theta_{1}(z)$ & $-0.343 \times 10^{-4} z+0.907$ \\
$\theta_{2}(z)$ & $0.030 z^{0.436}+0.177$ \\
$\theta_{3}(z)$ & $0.298+0.300 \times 10^{-4} z-0.663 \times 10^{-7} z^{2}$ \\
$\theta_{4}(z)$ & $0.422+0.190 \times 10^{-2} z-0.623 \times 10^{-5} z^{2}+0.595 \times 10^{-8} z^{3}$ \\
$\psi_{1}(z)$ & $-0.118 \times 10^{-3} z+0.057$ \\
$\psi_{2}(z)$ & $0.334 \times 10^{-2} z^{0.098}-0.606 \times 10^{-2}$ \\
$\psi_{3}(z)$ & $0.337 \times 10^{-3}+0.931 \times 10^{-6} z-0.032 \times 10^{-7} z^{2}$ \\
&
\end{tabular}

radiation, $R_{S}$, and multiple scattering and reflection between glacier surface and cloud cover, $R_{\mathrm{M}}$ (outlined in detail in Möller and others, 2011a). Direct solar radiation, $R_{\mathrm{D}}$, is calculated according to standard solar-geometry algorithms (Bernhardt and Philipps, 1958; Iqbal, 1984; Corripio, 2003). The reduction due to cloud cover is achieved by using the Savinov-Ångström formula (e.g. Kondratyev, 1969):

$$
R_{\mathrm{S}}=R_{\mathrm{D}}\left[1-\left(1-\eta^{\prime}\right) C C_{\mathrm{ERA}}\right]
$$

ERA-Interim total cloud-cover data, $C C_{\text {ERA, }}$ is taken as a spatially invariant quantity. The empirical coefficient, $\eta^{\prime}$, is taken to be 0.58 which equals the value at $80^{\circ} \mathrm{N}$ (Budyko and Miller, 1974). This means that a complete cloud cover reduces $R_{\mathrm{D}}$ by $42 \%$.

Multiple scattering and reflection is calculated as a fraction of $R_{\mathrm{S}}$ according to an empirical relation that was calibrated for conditions at Vestfonna by Möller and others (2011a):

$$
R_{\mathrm{M}}=R_{\mathrm{S}}\left(g \alpha C C_{\mathrm{ERA}} \frac{\mathrm{SV}}{\mathrm{SV}_{\mathrm{AWS}}}\right)
$$

Coefficient $g$ is given in Table $1, \alpha$ is the surface-albedo field, SV is the spatially distributed sky-view factor and $\mathrm{SV}_{\mathrm{AWS}}(0.88)$ is the value of the sky-view factor at the AWS.

\section{Calibration and validation}

Model calibration was based on a set of 29 multi-year, repeat measurements at a mass-balance stake network in the northwestern part of Vestfonna (Fig. 1) that was also used by Möller and others (2011a). Calibration was done by running the entire $\mathrm{CMB}$ model with iterative changes of parameters $e$ and $f$ until a minimum rmse was reached.

The model is validated using three independent massbalance datasets. A firn-core analysis of Beaudon and others (2011) provides a time series of annual mass balances for Ahlmann Summit that covers the period 1992-2009. Repeat stake measurements along the transect at the AWS (Fig. 1) that cover the period summer 2009 to summer 2011 and that were not included in the calibration procedure provide 14 seasonal and annual point balances from the ablation area. A comparison with modelling results of Greuell and others (2007) is also used for model validation. Greuell and others calculated surface mass-balance anomalies for several glaciers on the Svalbard archipelago for the mass-balance years 1999/2000-2004/05 using a newly presented method based on MODIS albedo data. Among these glaciers is Frazerbreen, a southern outlet glacier of Vestfonna (Fig. 1). To facilitate the comparison, we also calculated anomalies of surface mass balance, i.e. CMB without accounting for

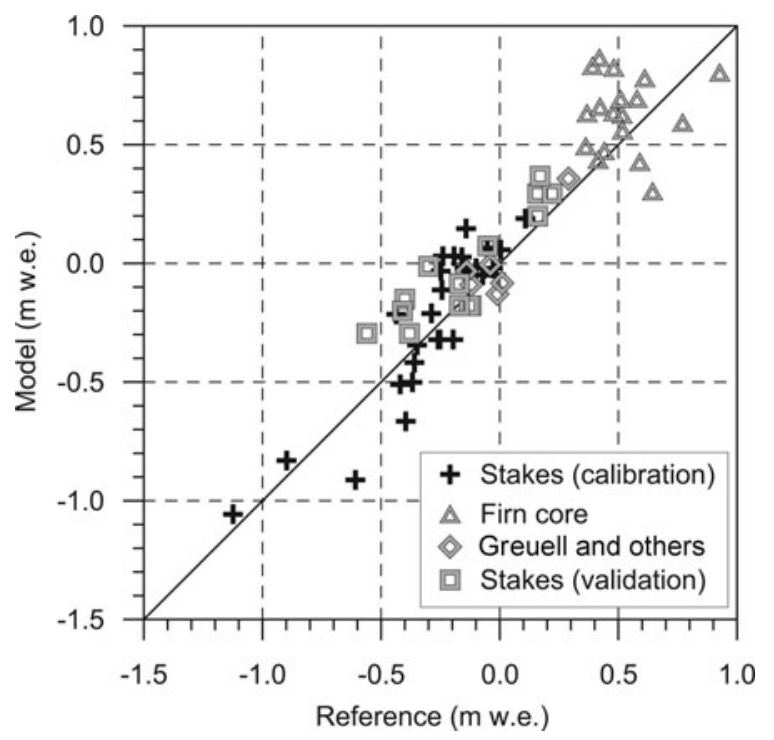

Fig. 3. Modelling performance of the reconstruction model during calibration and validation. Calibration is based on stake measurements of Möller and others (2011a). Independent model validation is performed using firn-core data from Ahlmann Summit for the period 1992-2009 (Beaudon and others, 2011), new stake measurements that were not considered by Möller and others (2011a) and a comparison between anomalies of modelled annual surface mass balances of the years 1999/2000-2004/05 of Frazerbreen (Fig. 1) and balance anomalies obtained by Greuell and others (2007).

refreezing, of Frazerbreen for this period from the model results of this study.

Validation results (Fig. 3) suggest a good model performance. The model reproduces the 38 independent massbalance values of the three validation datasets reasonably well. Overall, an rmse of $0.18 \mathrm{~m}$ w.e. $\mathrm{a}^{-1}$ is obtained when weighting the individual deviations according to measurement-period lengths. Modelled balances account for $81 \%$ of the variance of the mass balances used for validation. No apparent systematic over- or underestimations are noticeable (Fig. 3). Hence, the model proved able to provide an adequate reproduction of both the spatial and temporal variability of mass balance at the ice cap. The obtained rmse of the model validation is used as an error range when reporting annual balances in this study.

\section{RESULTS}

Results are presented and analysed by referring to the period 1979/80-2010/11 (32 years) and two shorter subsets of this period, i.e. 1989/99-2010/11 (22 years) and 1999/20002010/11 (12 years). This is done in order to obtain a better picture of both absolute mass-balance values and their temporal trends. The significance of these trends is calculated using the Mann-Kendall trend test (Kendall and Gibbons, 1990), that is based on an evaluation of the significance level of Kendall's rank correlation coefficient, $\tau$.

Möller and others (2011a) found September to be the start of the mass-balance year at Vestfonna and identified a characteristic duration of the ablation season from June to August. This finding also holds for the 32 year time series presented in this study (Fig. 4). Ablation indeed mostly lasts until September, but amounts in this month are small enough that accumulation predominates and the $\mathrm{CMB}$ 


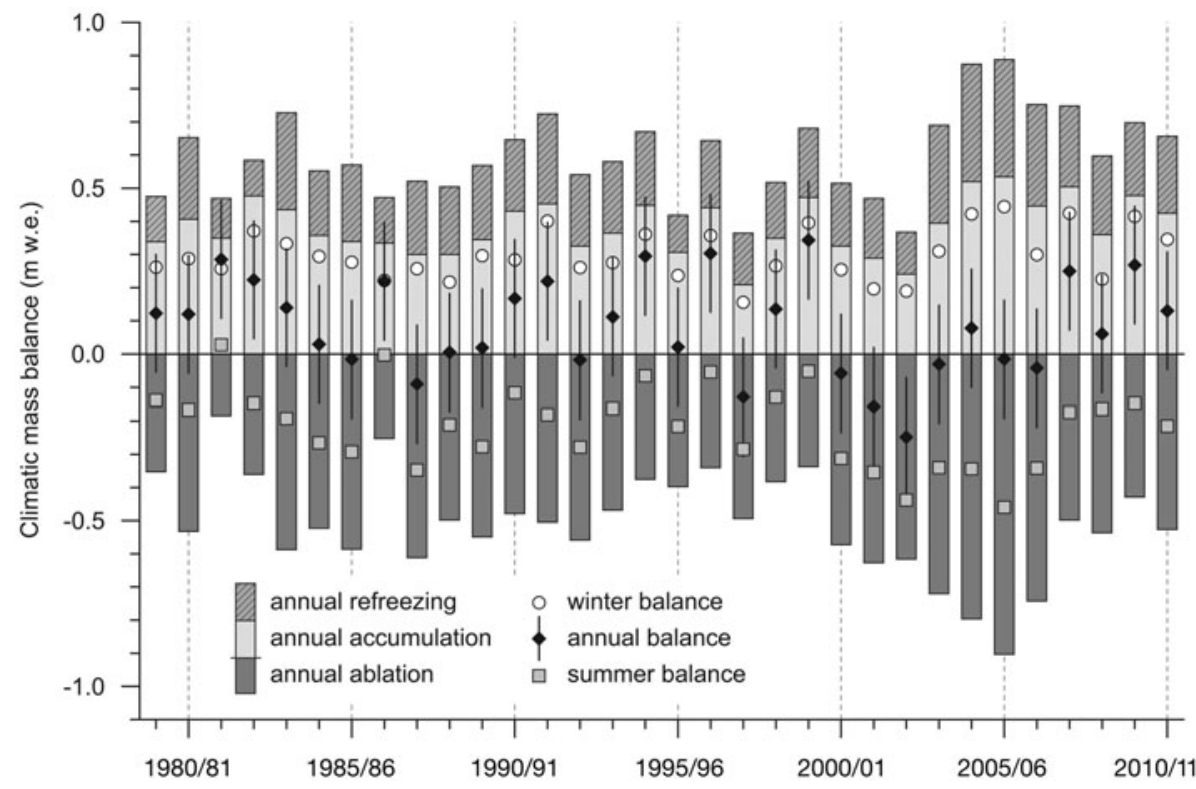

Fig. 4. Annual climatic mass-balance quantities for the period 1979/80-2010/11. The symbols show seasonal balances. The error bars represent the $\pm 0.18 \mathrm{~m}$ w.e. modelling error derived from model validation. The bar chart shows annual accumulation, ablation and refreezing. Each mass-balance year lasts from 1 September to 31 August, winter balances cover September-May and summer balances June-August.

becomes positive. Sporadically, minor ablation is still present in October. In December 2002 a small amount of melting even occurred in midwinter. Peak melting is regularly found either in July or sometimes in August. Accordingly, in this study we also calculate the winter balances over the period September-May and the summer balances over the period June-August.

Results indicate a positive mean $\mathrm{CMB}$ rate of $+0.09 \pm 0.15 \mathrm{~m}$ w.e. $\mathrm{a}^{-1}$ (mean \pm one standard deviation) for Vestfonna over the period 1979/80-2010/11 (Fig. 4; Table 3). The mean winter balance rate amounts to $+0.30 \pm 0.08 \mathrm{~m}$ w.e. $\mathrm{a}^{-1}$ while the summer balance rate shows a mean of $-0.21 \pm 0.12 \mathrm{~m}$ w.e. $\mathrm{a}^{-1}$. The high interannual fluctuations present within the time series of annual balances are governed by varying intensities of both ablation and accumulation seasons. While the influence of ablation becomes weaker over the study period, the influence of accumulation increases. The correlation of annual balance with annual ablation decreases over the three considered periods from $r=0.64(1979 / 80-2010 / 11)$ to 0.59 (1989/992010/11 and 1999/2000-2010/11). The correlation with annual accumulation, in contrast, shows an increase with time from $r=0.63(1979 / 80-2010 / 11)$ to $0.68(1989 / 99$ 2010/11) and 0.70 (1999/2000-2010/11).

Table 3. Characteristic mass-balance values at Vestfonna and their trends over three different periods. The 12 mass-balance quantities are given in $\mathrm{m}$ w.e., the climatic mass-balance gradient in $\mathrm{m}$ w.e. $(100 \mathrm{~m})^{-1}$ and the equilibrium-line altitude (ELA) in $\mathrm{m}$ a.s.l. All mean values are given with a \pm 1 standard deviation range. Trends are given per decade. Bold values indicate significance at the $90 \%$ level, underlined bold values significance at the $95 \%$ level

\begin{tabular}{|c|c|c|c|c|c|c|}
\hline \multirow[t]{2}{*}{ Quantity } & \multicolumn{2}{|c|}{ 1979/80-2010/11 } & \multicolumn{2}{|c|}{ 1989/90-2010/11 } & \multicolumn{2}{|c|}{ 1999/2000-2010/11 } \\
\hline & Mean & Trend & Mean & Trend & Mean & Trend \\
\hline Winter accumulation & $0.316 \pm 0.074$ & 0.025 & $0.329 \pm 0.082$ & 0.031 & $0.350 \pm 0.086$ & 0.070 \\
\hline Winter ablation & $-0.018 \pm 0.020$ & -0.003 & $-0.021 \pm 0.024$ & 0.003 & $-0.023 \pm 0.019$ & 0.019 \\
\hline Winter refreezing & $0.003 \pm 0.004$ & 0.001 & $0.004 \pm 0.005$ & 0.000 & $0.004 \pm 0.005$ & $-\overline{0.004}$ \\
\hline Winter CMB & $0.300 \pm 0.076$ & 0.021 & $0.310 \pm 0.084$ & 0.031 & $0.327 \pm 0.094$ & 0.079 \\
\hline Summer accumulation & $0.068 \pm 0.021$ & -0.003 & $0.064 \pm 0.017$ & 0.009 & $0.066 \pm 0.018$ & 0.029 \\
\hline Summer ablation & $-0.493 \pm 0.154$ & -0.067 & $-0.518 \pm 0.151$ & -0.090 & $-0.586 \pm 0.165$ & -0.010 \\
\hline Summer refreezing & $0.211 \pm 0.064$ & 0.025 & $0.222 \pm 0.064$ & 0.031 & $0.242 \pm 0.071$ & 0.059 \\
\hline Summer CMB & $-0.214 \pm 0.120$ & -0.045 & $-0.232 \pm 0.119$ & -0.051 & $-0.279 \pm 0.126$ & 0.077 \\
\hline Annual accumulation & $0.384 \pm 0.081$ & 0.022 & $0.393 \pm 0.089$ & 0.040 & $0.416 \pm 0.095$ & 0.099 \\
\hline Annual ablation & $-0.511 \pm 0.153$ & -0.070 & $-0.539 \pm 0.149$ & -0.087 & $-0.609 \pm 0.161$ & 0.009 \\
\hline Annual refreezing & $0.214 \pm 0.063$ & 0.026 & $0.225 \pm 0.063$ & 0.031 & $0.246 \pm 0.070$ & 0.054 \\
\hline $\mathrm{CMB}$ gradient & $0.356 \pm 0.067$ & $\underline{0.038}$ & $0.374 \pm 0.063$ & 0.042 & $0.404 \pm 0.067$ & 0.030 \\
\hline ELA & $326 \pm 55$ & 14 & $332 \pm 54$ & 14 & $345 \pm 55$ & -38 \\
\hline
\end{tabular}




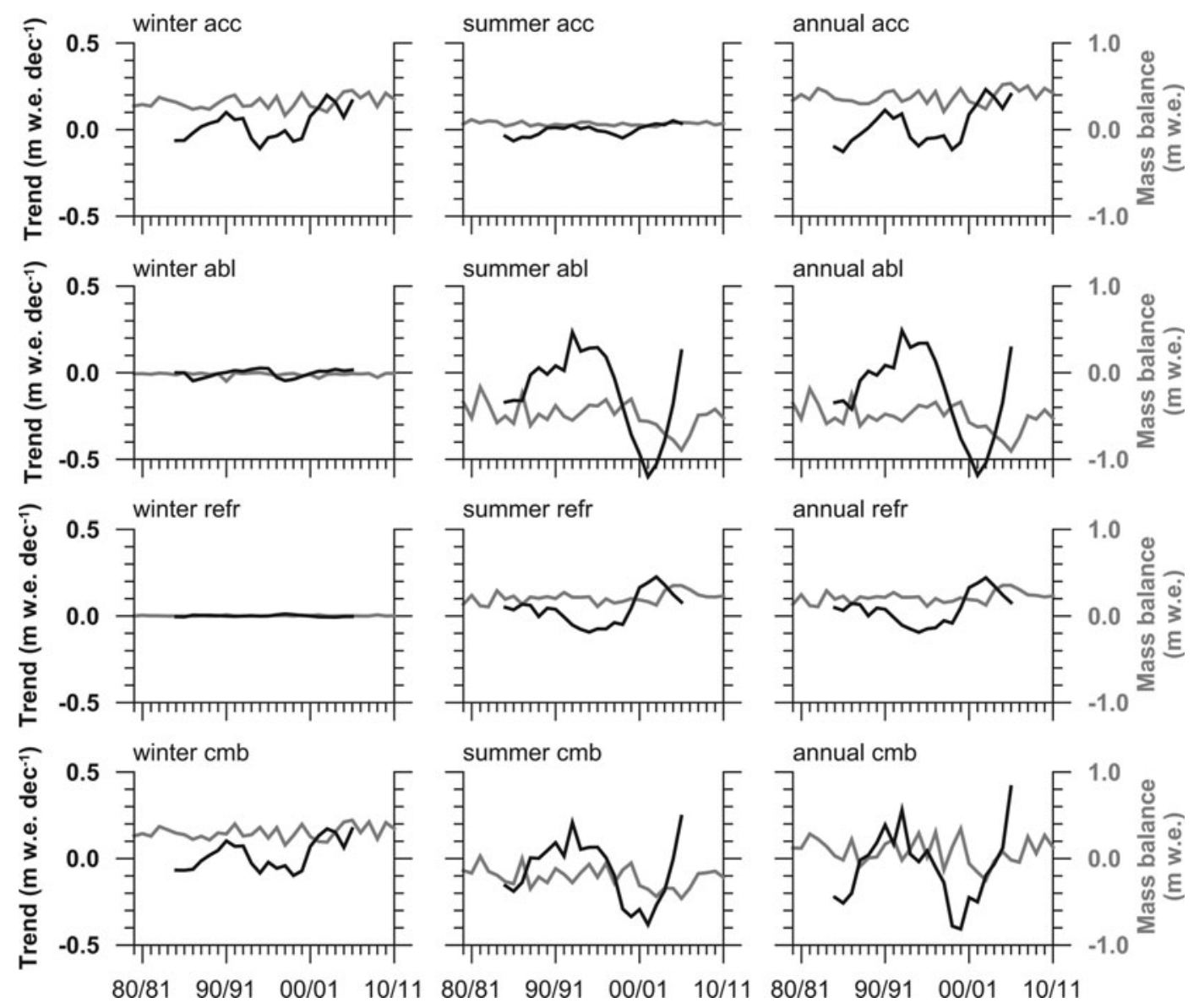

Fig. 5. Evolution of trends of the different mass-balance quantities over the period 1979/80-2010/11. Rows show accumulation, ablation, refreezing and CMB (from top to bottom). Columns show winter balance, summer balance and annual balance (from left to right). Each graph shows the mass-balance quantity (mw.e.; grey curve) and its running decadal trend (black curve). Each mass-balance year lasts from 1 September to 31 August, winter is from September until May and summer from June until August.

Refreezing is found to play a major role in mass conservation across the ice cap (Table 3). According to our estimates, $\sim 43 \%$ of the annual ablation $(+0.21 \pm 0.06 \mathrm{~m}$ w.e.) refreezes within the snow- or firn pack. However, as refreezing is controlled by an interplay of both winter accumulation and summer ablation, high interannual variability is present, and a range of +0.11 to $+0.36 \mathrm{~m}$ w.e. is observed for individual mass-balance years.

The most positive mass-balance year is 1999/2000 $(+0.34 \pm 0.18 \mathrm{~m}$ w.e.; Fig. 4). It mainly results from a combination of very low annual ablation $(-0.34 \mathrm{~m}$ w.e. $)$ and above-average annual accumulation ( $+0.47 \mathrm{~m}$ w.e.). A very high refreezing fraction (62\% of annual ablation) further boosts this positive coincidence. The most negative mass-balance year (2002/03, $-0.25 \pm 0.18 \mathrm{~m}$ w.e.; Fig. 4$)$, in contrast, is the product of very low annual accumulation $(+0.24 \mathrm{~m}$ w.e. $)$, well above-average annual ablation $(-0.62 \mathrm{~m}$ w.e. $)$ and the lowest refreezing fraction of the study period ( $21 \%$ of annual ablation).

Overall, the climatic mass-balance time series of Vestfonna is predominantly characterized by positive annual balances; only the period 2001/02-2006/07 differs from this general picture and shows a considerably negative mean (Fig. 4). Accordingly, the mean annual CMB rate decreases towards less positive values when related to the later periods 1989/99-2010/11 and 1999/2000-2010/11 (Table 3). Despite this apparent decrease, no significant trends are evident for the considered periods.
The annual exchange shows an increase with time (Fig. 4). On one hand, this development is based on increasing winter accumulation and thus winter balance (Fig. 5; Table 3). On the other hand, the significant negative trends of annual and summer ablation, and thus summer balance over the study period, (Table 3) further contribute to this development.

The increasing annual exchange results directly in an increased importance of refreezing. Potential refreezing increases with winter accumulation, and the more ablation occurs in the summer season the higher becomes the actual amount. Annual refreezing sums therefore exhibit a significant positive trend over the study period (Table 3 ).

The fact that summer melting significantly increases over the study period (Table 3; Fig. 5) suggests an associated extension of the characteristic 3 month ablation period. This is further supported by the slight but significant decrease in summer accumulation over the study period and the concurrent significant increase in winter ablation (Fig. 5; Table 3). Accordingly, the number of melt days at the AWS outside the ablation season increased from $2.1 \pm 3.5$ days per mass-balance year during the first half of the study period (1979/80-1994/95) to $3.0 \pm 3.1$ days during the second half of the study period (1995/96-2010/11). The high standard deviations indicate that this development is mainly based on isolated mass-balance years with large numbers of melt days outside the ablation seasons. However, the frequency of years where melt days outside the ablation 


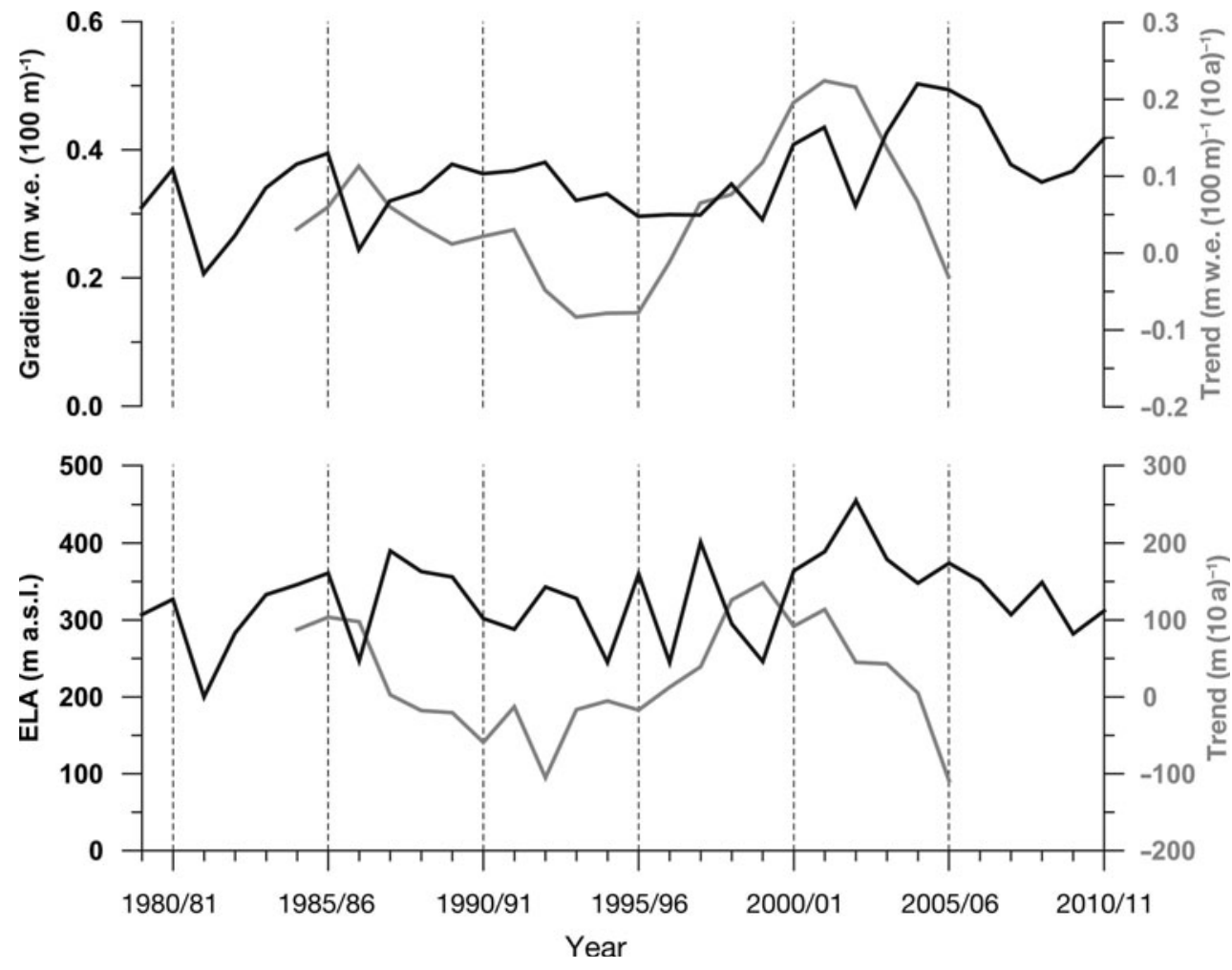

Fig. 6. Mean climatic mass-balance gradients and ELAs of the mass-balance years 1979/80-2010/11 (black curves). Running decadal trends are shown as grey curves. Each mass-balance year lasts from 1 September to 31 August.

season are present also increased from 9 to 14 from the first to the second half of the study period. This also indicates a slight lengthening of the ablation period in recent years.

The mean equilibrium-line altitude (ELA) at Vestfonna for the period $1979 / 80-2010 / 11$ is calculated as $326 \pm 55 \mathrm{~m}$ a.s.l. (mean \pm one standard deviation; Table 3; Fig. 6). During this period, it shows a slight but significant increase with time. In the period 1989/90-2010/11 the mean is $6 \mathrm{~m}$ higher than for the entire study period, and the mean ELA for the mass-balance years after $1999 / 2000$ is $19 \mathrm{~m}$ higher (Table 3). However, the interannual variability of the ELA is very high (Fig. 6) and the observed changes lie within one standard deviation of the mean $( \pm 55 \mathrm{~m})$. A reliable statement regarding the long-term trend of the ELA at Vestfonna can thus not be given.

The annual climatic mass-balance gradients at Vestfonna for the period 1979/80-2010/11 show a mean of $+0.36 \pm 0.07 \mathrm{~m}$ w.e. $(100 \mathrm{~m})^{-1}$ (Table 3$)$ and increase significantly with time (Fig. 6; Table 3). The mean gradients increase to $+0.37 \pm 0.06$ and $+0.40 \pm 0.07 \mathrm{~m}$ w.e. $(100 \mathrm{~m})^{-1}$ when referring to the periods 1989/90-2010/11 and 1999/ 2000-2010/11, respectively. Despite the inhomogeneous development of the trend over the study period (Fig. 6), these findings indicate a substantial steepening of the climatic mass-balance gradient at Vestfonna. This is also supported by the increasing annual exchange outlined above.

\section{DISCUSSION}

The modelled $\mathrm{CMB}$ rates correspond well with the findings of other Vestfonna-related studies. Nuth and others (2010) calculated a mean geodetic mass-balance $(\mathrm{GMB})$ rate for the ice cap of $+0.05 \pm 0.15 \mathrm{~m}^{\mathrm{w}} \mathrm{w} . \mathrm{a}^{-1}$ for the period 1990 2005 from a comparison of historical maps and Ice, Cloud and land Elevation Satellite (ICESat) data. The modelled annual $\mathrm{CMB}$ rates for this period show a mean of $+0.07 \pm 0.17 \mathrm{~m}$ w.e. $\mathrm{a}^{-1}$ and are thus of similar magnitude. This consistency also holds for a more recent period studied by Moholdt and others (2010a). They obtain mean winter and summer GMB rates for the periods 2004-08 and 200307 from repeat ICESat data $(+0.30 \pm 0.13$ and $-0.55 \pm$ $0.17 \mathrm{~m}$ w.e. $\left.\mathrm{a}^{-1}\right)$. Our modelling reveals comparable mean winter and summer $\mathrm{CMB}$ rates of $+0.38 \pm 0.07$ and $-0.39 \pm 0.06 \mathrm{~m}$ w.e. $\mathrm{a}^{-1}$ for these periods. The frequent positive bias of $\mathrm{CMB}$ can be explained by the fact that $\mathrm{GMB}$ includes calving-flux-induced mass losses and is thus generally more negative. The larger bias observed in summer is consistent with this, as a seasonal speed-up of outlet glaciers is expected. Dunse and others (2012) documented such behaviour for two basins of neighbouring Austfonna.

This picture becomes less consistent when findings on recent area changes of Vestfonna (Braun and others, 2011) are included. Since 1976 the ice cap has shown a continuous retreat at most of its calving fronts, despite the apparently positive CMB. Long-term comparisons of modelled $\mathrm{CMB}$ to firn-core-derived balance rates also reveal discrepancies. Modelling results fit well with mass-balance rates derived from the Beaudon and others (2011) 19922009 firn core from Ahlmann Summit $(+0.62 \pm 0.16$ compared to $+0.52 \pm 0.15 \mathrm{~m}_{\text {w.e. }} \mathrm{a}^{-1}$; Fig. 3). However, a comparison with rates obtained from firn cores drilled at the eastern summit of the ice cap reveal a substantial but varying positive bias of modelled $\mathrm{CMB}$ rates. The firn core drilled by Beaudon and others (2011) in 2007 indicates a mean massbalance rate of $+0.25 \pm 0.08 \mathrm{mw}$.e. $\mathrm{a}^{-1}$ for the period 1993-2005, and a firn core drilled in 1995 at almost the 
same location indicates a rate of $+0.41 \pm 0.05 \mathrm{~m}$ w.e. $\mathrm{a}^{-1}$ for the period 1986-94 (Pinglot and others, 1999). The modelled $\mathrm{CMB}$ rates for these periods amount to $+0.62 \pm 0.16$ and $+0.61 \pm 0.09 \mathrm{~m}^{\mathrm{w}}$.e. $\mathrm{a}^{-1}$, respectively.

This reveals a distinctly lower accumulation rate at the eastern summit of Vestfonna that is not reproduced by the model. Presumably this is because modelled accumulation depends on elevation only. Extensive snow-profile analysis from all over the ice cap, in contrast, revealed no significant zonal or meridional accumulation variability (Möller and others, 2011b). Taken together, this suggests that the accumulation-rate decline is largely limited to the area around the intersection of the two main ridges of Vestfonna. This, nevertheless, introduces an unquantifiable error into modelled CMB. However, this error can be assumed to be of minor magnitude, as the affected area around the eastern summit is small when compared to the entire extent of the ice cap.

The bias between modelled $\mathrm{CMB}$ rates and firn-corederived mass-balance rates at the eastern summit, moreover, shows a variation with time. It increases from +0.20 m w.e. in the period 1986-94 to +0.37 m w.e. in the period 19932005. This substantial difference suggests a change in the accumulation pattern of Vestfonna in the early 1990s that is not reproduced by the model. Hence, the unquantifiable error of modelled $\mathrm{CMB}$ in the area around the eastern summit of the ice cap has to be assumed to show considerable variability with time.

When comparing our results for Vestfonna to contemporaneous Austfonna balances, distinct similarities arise. For the winter season 1998/99 Pinglot and others (2001) obtained specific mass balances of up to about $+0.7 \mathrm{~m}$ w.e. for Austfonna, while the profile of winter CMB at Vestfonna shows values of up to about $+0.4 \mathrm{~m}$ w.e. during this season. Considering the generally lower precipitation on Vestfonna (Pinglot and others, 1999) this can be seen as a reasonable agreement. The Etonbreen/Winsnesbreen basin in the western part of Austfonna shows increasing annual mass balances over the period spring 2004 to spring 2008 (Moholdt and others, 2010b). This overall pattern is also found in the modelled $\mathrm{CMB}$ time series of Vestfonna (Fig. 4). The substantial decrease of the ELA that was monitored at Austfonna during this period (Moholdt and others, 2010b) also appears at Vestfonna (Fig. 6). Correspondingly, the measured mean annual balance rate of the Etonbreen/Winsnesbreen basin (+0.02 mw.e. $\left.\mathrm{a}^{-1}\right)$ agrees well with the modelled mean annual CMB rate of Vestfonna $\left(+0.04\right.$ m w.e. $\left.\mathrm{a}^{-1}\right)$.

In contrast to this, remarkable differences appear when comparing the mass-balance evolution of Vestfonna with available time series for other glaciers on Svalbard. Rasmussen and Kohler (2007) presented reconstructed mass-balance time series for Austre Brøggerbreen, Midre Lovénbreen and Kongsvegen. Their results reveal a distinctly higher annual exchange for these glaciers at the western coast of Spitsbergen. Vestfonna experiences only half of this. Moreover, the winter balance of these three glaciers shows a clear tendency towards less positive balances since the mid-1980s, i.e. a development in the opposite direction to that found for Vestfonna. The pattern of interannual winter-balance variability is also distinctly different at Vestfonna than at the glaciers in the Ny-Ålesund area. The tendency towards more negative summer balances, however, is in line with our findings for Vestfonna.
The interannual summer-balance pattern also shows considerable similarities with the one obtained for Vestfonna.

The results of this study compare well with the results of the CMB modelling study of Möller and others (2011a), despite the improved air-temperature downscaling and the increased $P_{\max }$ value. However, as we recalibrated the model after changing its formulation, substantially different $\mathrm{CMB}$ values could only occur above the ELA during summer. The mean glacier-wide annual, summer and winter $\mathrm{CMB}$ rates that are obtained over the period studied by Möller and others (2011a), i.e. 2000/01-2008/09, are thus comparable in both studies. However, the mean CMB gradient calculated here for this period $\left(+0.42 \mathrm{mw}\right.$.e. $\left.(100 \mathrm{~m})^{-1}\right)$ is distinctly steeper than the one calculated by Möller and others (2011a) $\left(+0.31 \mathrm{~m}\right.$ w.e. $\left.(100 \mathrm{~m})^{-1}\right)$. This reflects the interacting influences of increased refreezing amounts throughout the upper parts of the ice cap during summer and the increased ablation sums that occur as a result of the higher melt factors of the recalibrated CMB model.

\section{CONCLUSIONS}

The climatic mass balance of Vestfonna was reconstructed for the period 1979/80-2010/11. A positive mean CMB rate $\left(+0.09 \pm 0.15 \mathrm{~m}\right.$ w.e. $\left.\mathrm{a}^{-1}\right)$ was obtained for the study period. It shows a slight but insignificant trend towards less positive values. In line with this, the mean ELA (326 \pm 55 ma.s.I.) also shows a slight but insignificant increase over the study period. Annual ablation was found to be the main governing factor for the variability of annual balances in the beginning of the study period, while annual accumulation takes over towards the end. Moreover, there are indications of an extension of the characteristic 3 month ablation period.

Refreezing was found to be a major contributor to mass conservation. Using the $P_{\max }$ approach it was estimated that, on average, $\sim 43 \%$ of annual ablation $(+0.21 \pm 0.06 \mathrm{~m}$ w.e. $)$ refreezes within the snow or firnpack. The refreezing is approximately one-third of the mean annual accumulation, i.e. annual surface accumulation plus refreezing, of the ice cap, and despite its high interannual variability it shows a significant positive trend over the study period.

A tendency towards increased annual exchange was observed. This development results from a combination of the slight tendency towards more positive winter balances and the significant negative trend of summer balances that were revealed for Vestfonna. It can also be seen as the reason for the increasing refreezing sums and for the significant positive trend and thus the steepening of the climatic mass-balance gradient that is evident at the ice cap over the study period.

The mass-balance evolution at Vestfonna shows similarities to neighbouring Austfonna. Compared to glaciers in the Ny-Ålesund area, similarities arise when looking at interannual variability or the tendency towards more negative summer balances during recent decades. However, regarding the evolution of winter balances, a development in the opposite direction is evident.

\section{ACKNOWLEDGEMENTS}

This study was funded by grant Nos. BR 2105/6-1, SCHE 750/ 3-1, SCHN 680/2-1 and SCHN680/2-2 of the German Research Foundation (DFG). Additional funding was provided by grant Nos. 03F0623A and 03F0623B of the German 
Federal Ministry of Education and Research (BMBF). The ERAInterim data used in this study are provided by the European Centre for Medium-Range Weather Forecasts (ECMWF). Comments by Thorben Dunse, Tómas Jóhannesson and an anonymous reviewer helped to improve the manuscript and are gratefully acknowledged. We thank Emilie Beaudon for providing annual-resolution firn-core data, and Veijo A. Pohjola for providing parts of the stake data.

\section{REFERENCES}

Beaudon É and 7 others (2011) Spatial and temporal variability of net accumulation from shallow cores from Vestfonna ice cap (Nordaustlandet, Svalbard). Geogr. Ann. A, 93(4), 287-299 (doi: 10.1111/j.1468-0459.2011.00439.x)

Bernhardt F and Philipps H (1958) Die räumliche und zeitliche Verteilung der Einstrahlung, der Ausstrahlung und der Strahlungsbilanz im Meeresniveau, Teil 1: Die Einstrahlung. (Abhandlungen des Meteorologischen und Hydrologischen Dienstes der Deutschen Demokratischen Republik 45). Akademie-Verlag, Berlin

Braun $\mathrm{M}$ and 7 others (2011) Changes of glacier frontal positions of Vestfonna (Nordaustlandet, Svalbard). Geogr. Ann. A, 93(4), 301-310 (doi: 10.1111/j.1468-0459.2011.00437.x)

Budyko MI and Miller DH (1974) Climate and life. Academic Press, New York

Cogley JG and 10 others (2011) Glossary of glacier mass balance and related terms. (IHP-VII Technical Documents in Hydrology 86) UNESCO-International Hydrological Programme, Paris

Corripio JG (2003) Vectorial algebra algorithms for calculating terrain parameters from DEMs and solar radiation modelling in mountainous terrain. Int. J. Geogr. Inf. Sci., 17(1), 1-23

Dee DP and 35 others (2011) The ERA-Interim reanalysis: configuration and performance of the data assimilation system. Q. J. R. Meteorol. Soc., 137(656), 553-597 (doi: 10.1002/qj.828)

Dowdeswell JA and Collin RL (1990) Fast-flowing outlet glaciers on Svalbard ice caps. Geology, 18(8), 778-781

Dunse T, Schuler TV, Hagen JO and Reijmer CH (2012) Seasonal speed-up of two outlet glaciers of Austfonna, Svalbard, inferred from continuous GPS measurements. Cryosphere, 6(2), 453-466 (doi: 10.5194/tc-6-453-2012)

Førland EJ, Hanssen-Bauer I and Nordli PØ (1997) Climate statistics and long-term series of temperature and precipitation at Svalbard and Jan Mayen. (DNMI Rapp. 21/97 KLIMA) Norsk Meteorologisk Institutt, Oslo

Gardner AS and 8 others (2011) Sharply increased mass loss from glaciers and ice caps in the Canadian Arctic Archipelago. Nature, 473(7347), 357-360 (doi: 10.1038/nature10089)

Greuell W and 6 others (2007) Assessment of interannual variations in the surface mass balance of 18 Svalbard glaciers from the Moderate Resolution Imaging Spectroradiometer/Terra albedo product. J. Geophys. Res., 112(D7), D07105 (doi: 10.1029/ 2006JD007245)

Huth R (1999) Statistical downscaling in central Europe: evaluation of methods and potential predictors. Climate Res., 13(2), 91-101 (doi: 10.3354/cr013091)

Huth R, Kyselý J and Dubrovský M (2001) Time structures of observed, GCM-simulated, downscaled and stochastically generated daily temperature series. J. Climate, 14(20), 4047-4061 (doi: 10.1175/1520-0442(2001)014<4047:TSOOGS>2.0.CO;2)

Iqbal M (1984) An introduction to solar radiation. Academic Press, New York

Jacob T, Wahr J, Pfeffer WT and Swenson S (2012) Recent contributions of glaciers and ice caps to sea level rise. Nature, 482(7386), 514-518 (doi: 10.1038/nature10847)

Jania J, Mochnacki D and Gadek B (1996) The thermal structure of Hansbreen, a tidewater glacier in southern Spitsbergen, Svalbard. Polar Res., 15(1), 53-66 (doi: 10.1111/j.1751-8369.1996. tb00458.x)
Karl TR, Wang W-C, Schlesinger ME, Knight RW and Portman D (1990) A method relating general circulation model simulated climate to the observed local climate. Part I: seasonal statistics. J. Climate, 3(10), 1053-1079 (doi: 10.1175/1520-0442(1990) 003<1053:AMORGC > 2.0.CO;2)

Kaser G, Cogley JG, Dyurgerov MB, Meier MF and Ohmura A (2006) Mass balance of glaciers and ice caps: consensus estimates for 1961-2004. Geophys. Res. Lett., 33(19), L19501 (doi: 10.1029/ 2006GL027511)

Käsmacher O and Schneider C (2011) An objective circulation pattern classification for the region of Svalbard. Geogr. Ann. A, 93(4), 259-271 (doi: 10.1111/j.1468-0459.2011.00431.x)

Kendall MG and Gibbons JD (1990) Rank correlation methods, 5th edn. Griffin, London

Kondratyev KYa (1969) Radiation in the atmosphere. Academic Press, New York

Lefauconnier B, Hagen JO, Örbæk JB, Melvold $\mathrm{K}$ and Isaksson $\mathrm{E}$ (1999) Glacier balance trends in the Kongsfjorden area, western Spitsbergen, Svalbard, in relation to the climate. Polar Res., 18(2), 307-313

Loeng H (1991) Features of the physical oceanographic conditions of the Barents Sea. Polar Res., 10(1), 5-18 (doi: 10.1111/j.17518369.1991.tb00630.x)

Moholdt G, Nuth C, Hagen JO and Kohler J (2010a) Recent elevation changes of Svalbard glaciers derived from ICESat laser altimetry. Remote Sens. Environ.,114(11), 2756-2767 (doi: 10.1016/ j.rse.2010.06.008)

Moholdt G, Hagen JO, Eiken T and Schuler TV (2010b) Geometric changes and mass balance of the Austfonna ice cap, Svalbard. Cryosphere, 4(1), 21-34 (doi: 10.5194/tcd-3-857-2009)

Möller M (2012) A minimal, statistical model for the surface albedo of Vestfonna ice cap, Svalbard. Cryosphere, 6(5), 1049-1061 (doi: 10.5194/tc-6-1049-2012)

Möller M, Schneider C and Kilian R (2007) Glacier change and climate forcing in recent decades at Gran Campo Nevado, southernmost Patagonia. Ann. Glaciol., 46, 136-144 (doi: 10.3189/172756407782871530)

Möller M and 7 others (2011a) Climatic mass balance of the ice cap Vestfonna, Svalbard: a spatially distributed assessment using ERAInterim and MODIS data. J. Geophys. Res., 116(F3), F03009 (doi: 10.1029/2010JF001905)

Möller M and 11 others (2011b) Snowpack characteristics of Vestfonna and De Geerfonna (Nordaustlandet, Svalbard) - a spatiotemporal analysis based on multiyear snow-pit data. Geogr. Ann. A, 93(4), 273-285 (doi: 10.1111/j.1468-0459. 2011.00440.x)

Nuth C, Moholdt G, Kohler J, Hagen JO and Kääb A (2010) Svalbard glacier elevation changes and contribution to sea level rise. J. Geophys. Res., 115(F1), F01008 (doi: 10.1029/2008JF001223)

Østby T, Schuler TV, Hagen JO, Reijmer CH and Hock R (2013) Parameter uncertainty, refreezing and surface energy balance modelling at Austfonna ice cap, Svalbard, over 2004-2008. Ann. Glaciol., 54(63), see paper in this issue

Pellicciotti F, Brock BW, Strasser U, Burlando P, Funk $M$ and Corripio JG (2005) An enhanced temperature-index glacier melt model including shortwave radiation balance: development and testing for Haut Glacier d'Arolla, Switzerland. J. Glaciol., 51(175), 573-587 (doi: 10.3189/172756505781829124)

Pinglot JF and 6 others (1999) Accumulation in Svalbard glaciers deduced from ice cores with nuclear tests and Chernobyl reference layers. Polar Res., 18(2), 315-321 (doi: 10.1111/ j.1751-8369.1999.tb00309.x)

Pinglot JF, Hagen JO, Melvold K, Eiken T and Vincent C (2001) A mean net accumulation pattern derived from radioactive layers and radar soundings on Austfonna, Nordaustlandet, Svalbard. J. Glaciol., 47(159), 555-566 (doi: 10.3189/ 172756501781831800)

Radić V and Hock R (2011) Regionally differentiated contribution of mountain glaciers and ice caps to future sea-level rise. Nature Geosci., 4(2), 91-94 (doi: 10.1038/ngeo1052) 
Rasmussen LA and Kohler J (2007) Mass balance of three Svalbard glaciers reconstructed back to 1948. Polar Res., 26(2), 168-174 (doi: 10.1111/j.1751-8369.2007.00023.x)

Reeh N (1991) Parameterization of melt rate and surface temperature on the Greenland ice sheet. Polarforschung, 59(3), 113-128

Rotschky G, Schuler TV, Haarpaintner J, Kohler J and Isaksson E (2011) Spatio-temporal variability of snowmelt across Svalbard during the period 2000-08 derived from QuikSCAT/SeaWinds scatterometry. Polar Res., 30(5963) (doi: 10.3402/polar. v30i0.5963)

Rye CJ, Arnold NS, Willis IC and Kohler J (2010) Modeling the surface mass balance of a high Arctic glacier using the ERA-40 reanalysis. J. Geophys. Res., 115(F2), F02014 (doi: 10.1029/ 2009JF001364)
Strozzi T, Kouraev A, Wiesmann A, Wegmüller $U$, Sharov A and Werner C (2008) Estimation of Arctic glacier motion with satellite L-band SAR data. Remote Sens. Environ., 112(3), 636-645 (doi: 10.1016/j.rse.2007.06.007)

Svendsen $\mathrm{H}$ and 14 others (2002) The physical environment of Kongsfjorden-Krossfjorden, an Arctic fjord system in Svalbard. Polar Res., 21(1), 133-166 (doi: 10.1111/j.1751-8369. 2002.tb00072.x)

Von Storch H (1999) On the use of 'inflation' in statistical downscaling. J. Climate, 12(12), 3505-3506 (doi: 10.1175/ 1520-0442(1999)012<3505:OTUOII>2.0.CO;2)

Walczowski W and Piechura J (2011) Influence of the West Spitsbergen Current on the local climate. Int. J. Climatol., 31(7), 1088-1093 (doi: 10.1002/joc.2338) 